\title{
The problem of preserving and strengthening the occupational health of the teacher: a historical aspect
}

\author{
Grygorii Tereshchuk ${ }^{1, *}$, Halyna Meshko, ${ }^{1, * *}$, Miroslav Prochazka ${ }^{2, * * *}$, Oleksandr Meshko ${ }^{1, * * * *}$, and Halyna Radchuk ${ }^{1, \dagger}$ \\ ${ }^{1}$ Ternopil Volodymyr Hnatiuk National Pedagogical University, 2 Maksyma Kryvonosa Str., Ternopil, 46027, Ukraine \\ ${ }^{2}$ Institute of Pedagogy, University of South Bohemia in Ceske Budejovice, Branišovská 1645/31A, 37005 České Budějovice, Czechia
}

\begin{abstract}
The article is devoted to the retrospective analysis of the problem of the teacher's occupational health maintaining and strengthening. On the basis of the study of the psychological and pedagogical massive of sources the state of the development of the problem and the peculiarities of the research of the determined problem in history of the scientific thought and practice are defined. The periods and directions of the professional health of the teacher preservation and strengthening research problem are singled out and characterized. New views of the scientists who studied the problems of the optimization of the efficiency, manufacturing safety, improvement of the efficiency, overcoming of the professional weariness are presented. The experience of the pedagogical education of the beginning of the XX century in Russia and the Committee of the study of the teacher labour in particular, the study of the conditions and mechanisms of the professional disadaptation appearance, professional deformations, determination of the professional difficulties, their influence on the teacher's state of health are described. The positions of the scientists-analytics in the researched problem are shown. The crucial attention is devoted to the analysis of the A. Makarenko, V. Sukhomlinskyi views of the questions of study of the reasons of the teacher's health deterioration, the ways and means of the emotional stress removal, improvement of his psychological wellbeing. The special literature for the period from the middle of the XX century till the beginning of the XXI century on the problem of pedagogy and psychology of health, maintaining and strengthening of the teacher's health are analyzed. The circle of problems that need the research of the concrete ways of maintaining and strengthening of the teacher's health problem solving is determined.
\end{abstract}

\section{Introduction}

Today, the school needs a competent teacher, capable of personal and professional growth, to maintain a "professional form", to achieve professional longevity. The state of the teacher's occupational health affects the results of the pedagogical activity, influences the stability of the results of work, and determines the self-efficacy of his personality. In addition, occupational health largely depends on the health status of students, their socio-psychological well-being, and their "viability". A teacher with low occupational health is unable to create a psychologically safe educational and learning environment at school. He cannot shape the students' health culture because it requires a personal example.

The professional health of the teacher is an integral characteristic of the functional state of the organism, the global mental state of the person, characterized by the dynamic harmony of internal experiences and the related effectiveness and success of pedagogical activity, the ability

\footnotetext{
*e-mail: g.tereschuk@tnpu.edu.ua

**e-mail: hal-meshko@ukr.net

***e-mail: mproch@pf.jcu.cz

****e-mail: meshko_o@ukr.net

†e-mail: galyna012345@gmail.com
}

to withstand the negative factors that accompany this activity [1].

Therefore, the issue of preserving and promoting the health of the teacher is one of the priorities in his life and professional interests. Preserving and promoting the health of the teacher is an urgent problem of pedagogical and psychological science, and at the same time a strategic issue of the modern school.

The problem of health promotion and preservation has a long history. The study of it has always been given attention at different stages of the development of human society. Doctors, ecologists, valeologists, philosophers, educators, psychologists, representatives of various fields of science investigated the phenomenon of health, its essence, to learn how to manage it, to economically use health during the life and professional activity and find means for its preservation and strengthening.

In scientific sources there are works concerning the problem of formation of health culture in the history of theoretical thought [2], the state of elaboration of the problem of forming a healthy way of life of the future teacher [3], research of the phenomenon of "burnout" in retrospect [4], historical aspects of occupational health of specialists in industrial sphere [5]. 
The historical aspect of preserving and promoting the occupational health of the teacher has not yet been reflected in the psycho-pedagogical literature. The purpose of the article is to analyze the state of development and genesis of research into the problem of preserving and enhancing the teachers' occupational health in the history of scientific thought and practice; identify positive ideas for creative use in modern conditions.

Chronological boundaries of the study: a period of the beginning of the XX century - beginning of the XXI century. The definition of the lower boundary is connected with the emergence of the movement for scientific organization of work the development of issues of occupational health of workers. The and upper limit of the study is due to the emergence of a series of psychological and pedagogical studies on the problem of preserving the occupational health of the teacher.

\section{Methodology of research}

The methodological basis of the study covers the following scientific and theoretical approaches: historicalgenetic, interpretative-analytical, historical-systemic and historical-comparative to formulate conclusions and identify positive experiences for the use in the system of modern pedagogical education; search and bibliographic to obtain factual material from scientific research on the problem of preserving and promoting the health of the teacher; historical and pedagogical analysis, which made it possible to substantiate the genesis of the problem under study; biographical - to analyze the activities of scientists who have promoted the need to preserve and research the occupational health of teachers. The choice of research methods takes into account the interdisciplinary nature of the work. The following methods were used in the study: the dialectical method - to consider the problem of the study in all its relationships and dependencies; comparative-historical and hermeneutic methods for analysis, synthesis, generalization, systematization of scientific sources, legal framework of the problem of preserving and enhancing the occupational health of teachers, which ensured the insight into the nature and state of development of the problem under study, formulation of basic provisions and conclusions; chronological and diachronic - to track the development of ideas for preserving and promoting the health of the teacher; a prognostic method that made it possible to determine the possibility of using positive ideas of the past in the present conditions.

The source of the study is: documents on pedagogical education scientific researches (articles in scientific periodicals, monographs, theses, textbooks and manuals) of foreign and domestic scientists on the problems of preserving and promoting the health of the teacher; documentation of institutions of higher and postgraduate pedagogical education.

\section{Results of research}

\subsection{The research, in which the study of teachers' health preservation and strengthening problem was initiated}

Occupational health is one of the factors of occupational suitability, an important condition for the efficiency of work and an indicator of "quality" of professional life. The development of occupational health issues for workers dates back to the early twentieth century and is associated with the emergence of the Movement for Scientific Organization of Labor. Its founder, American engineer F. Taylor, in his work, proceeded from the concept of "economic man", considered the worker as an element of the production process. without being interested in his physical and mental well-being [6]. One of the leaders of the movement for the scientific organization of labor, F. Gilbreth saw the task and meaning of the scientific organization of labor is that everyone is engaged in the thing that most contributes to the development of his physical and mental abilities. Everyone should feel the joy of work, which is the main success of the Scientific Organization of Labor [7]. And he considered the health of workers as the first condition of work and its productivity. Therefore, to maintain the health of workers, it is necessary to rationalize their workplace, provide them with the necessary rest, reduce the impact of various fatigue. F. Gilbreth initiated the Day for Combating Fatigue, which was held annually in December. He insisted on the involvement of psychologists to solve the problems of staff in the workplace.

Psychological aspects of the scientific organization of work were also interesting for L. Gilbreth, who was the first woman in America to receive a doctorate in psychology $[8,9]$. She noted that good organization of work should consider the body and soul of the specialist in unity, focus not only on the professional, mental and moral development of workers but also form their desire for a healthy lifestyle (Gilbreth, as cited in [5, p. 481]. Occupational health issues at one time or another are being developed in England and Germany. Scientists in these countries investigated the problems of optimization of work organization, production safety, the problem of increasing vital energy, the phenomenon of occupational fatigue and its impact on performance.

The interest in the problem of preserving the health of employees led to various studies in various fields of knowledge, the creation of scientific laboratories, institutes and more. In the early twentieth century in Russia, the topic of occupational health was presented in the scientific-practical activity of V. Bekhterev, A. Gastev. At the initiative and under the direction of V. Bekhterev in Petrograd, the Institute for the Study of the Brain and Mental Activity was established in 1918, which included a Laboratory. The main task of the laboratory was to develop the issues and measures of harmonization and improvement of a work process, occupational health, and health in general. The Institute of the Brain organized the publication of popular scientific books on various issues of general hygiene and occupational health [10]. A. Gastev, 
the founder of the Central Institute of Labor in Moscow, paid special attention to ensuring the physical and mental health of workers. For this purpose, he believed, it is necessary to create the necessary working conditions: prevention of fatigue; training of the employee's physical properties; development of his observation, motor abilities, willpower, ability to manage their own time and so on. The main thing - to maximize the power of professionals in combination with the preservation of their strength and health, economical consumption of their energy [11]. At this time I. Mechnikov noted that professional activity influences life expectancy and, without a doubt, influences the state of mental and physical health of the subject of professional activity - occupational health (as cited in [5, p. 485]. At the same time, occupational health is considered to be a component of a professional's suitability.

The 1920s years were marked by a lively discussion about the ways of developing a managerial science, which in one way or another touched upon the issue of occupational health, namely: the question of the relationship between work motivation and health of employees; the role of stimulating workflow; the need for an objective and thorough study of performance and the factors that affect it, etc.

\subsection{Retrospective analysis of the problem of teachers' health preserving and strengthening (early XX - 70s of XX century)}

The results of the study of the scientific literature give us an opportunity to state that in the early twentieth century, considerable experience of pedagogical education was developed in Russia. In 1910, at the First Congress of Experimental Pedagogy was held in Moscow, where a student of Leipzig University T. Markaryan made a report on the problems of a teacher. Subsequently, he defended a doctoral dissertation in which a significant place was given to the pedagogical direction - didascology, which was interpreted by the author as a complex science about the teacher. Didascology argued that it was impossible to treat the child seriously and the teacher unseriously. This scientific area was supported in post-revolutionary Russia. In 1920, under the leadership of T. Markaryan at the Central Pedagogical Institute in Moscow, a Commission for the Study of Teachers was established, and in 4 years a program of activity of an independent teaching institute program was proposed for discussion [12].

All the work with the teachers, organized by the Teacher's work Learning Commission, had to help teachers become aware of their capabilities and be ready to present themselves (self-presentation). It relied on the psychological and cultural foundations of pedagogical work, because it offered the training of a teacher who was able to own and be able to "grow up" with children of children's culture. The methodological foundations of the research had been identified, a number of theoretical ideas had been put forward and substantiated (about the need for a comprehensive approach to the study of the teacher's problem, about the development of his personality, about self-education and the need for professional training of the teacher) [13]. In 1925 the book "The study of the professions of intelligent work" [14] was published, and a year later - the book "The work and health of a teacher" (edited by I. Ravkin and Y. Sokolov) [15].

A group of researchers (A. Shafranova, M. Rubinshtein, V. Kashkadamov, and M. Rybnikov) studied the problems of teacher fatigue, in particular, the dynamics of their performance, conditions and mechanisms of professional maladaptation. Even then, it was discovered that fatigue occurs after 4 hours of work. Based on the data obtained A. Shafranova created a classification of professions (as cited in [16, pp. 57-64]:

- professions of the higher type based on the characteristic "the need for constant work on the subject and myself". This group includes the professions of the representatives of education, art, doctors, and engineers;

- middle-class professions that require work only on the subject;

- professions of the lower type, which after graduation do not require special work on themselves and the subject of activity.

The "higher professions" group peculiarities include the following characteristics: always a new work, a number of completely inaccessible to our observation moments, and the available moments require a special psychological analysis; in workers of mechanical labor, the properties of the product are determined by the tools of production, and here - the nature and properties of the personality of the employee (in our case - the properties of students are determined by the properties of the teacher). The need was determined through special training to develop to the perfection the ability because otherwise the violence against the psychic will be carried out and depression, irritability and fatigue will appear as a result. The fatigue was explained by "high volition of incentive participation", constant, active thinking work, complexity and variety of work.

Researches wrote about the occupational deformation of the teacher's personality, which causes huge stresses to the nervous system and the emotional sphere. Overload is often not realized by the teacher. Continuous creativity and extra-curricular work on yourself and the subject, constant "activation of volitional impulse", an incredible number of requirements, frequent nonspecific emotions - all this does not go without a trace. At the same time, teachers experience "mental fatigue", occupational maladaptation, and occupational deformities as they gain experience, develop their approach, work style, and professional position. The very same "pedagogical system, organized in the previous form", L. Vygotsky argued [17], "is a place for educating a teacher's abnormality and creating a teacher's neurosis" [17, p. 459]. The great danger, said L. Vygotsky, is that "the teacher begins to feel like an instrument of education, a gramophone that has no voice and sings what the plate suggests. It must be said that any teaching profession imposes indelible typical features on its medium and creates pathetic figures who act as apostles of the walking truth. No wonder the teacher, this lively precept, always seemed humorous figure, the subject of jokes and 
ridicule and has always been a comic character, from ancient comedies to modern stories" [17, p. 459].

Analyzing the work of the teacher, M. Rubinshtein in his work "Problems of the teacher" emphasized that only an emotionally mature personality can overcome the difficulties of pedagogical activity. The scientist warned beginning teachers that emotionally, the teacher must improve himself to survive, to "keep himself alive in conditions where there is no cultural and professional support", and not to degrade as a person. To do this, the teacher must develop to perfection their potential capabilities, natural inclinations, abilities, master the basics of science, to create their personality based on natural and cultural. The scientist noted that the teacher needs to develop the ability to "use another's psyche, even reincarnate, but not dissolve in it", "stand taller, but not put yourself above others" [18]. The terms "empathy", "emotional burnout syndrome" were introduced into scientific circulation much later.

V. Kashkadamov's ideas about researching the health of teachers and the factors of their professional activity were also interesting. He believed that health was a prerequisite for the teacher's activity and self-realization. Teachers' health can be ensured by observing the general order of life, which implies the organization of proper nutrition, living conditions, the content of the professional activity, nature of recreation, entertainment [19].

In 1928, when comprehensive studies of teachers were conducted, the study of professional difficulties began. The following groups of teachers' difficulties were distinguished [20, p. 163]:

- high nervous and mental stress,

- children's mass as a teacher irritator,

- tension of the "working" organs in the somatic sphere (upper respiratory tract, larynx, visual organs, hearing),

- sanitary and hygienic conditions,

- the mode of work,

- social and living conditions.

As we can see, life's difficulties, in general, were considered, not just those which were related to the pedagogical activity, and difficulties that could affect the health of the teacher.

In the late 1920s, didascology was proclaimed the leader of bourgeois individualism, for a long time, proved undesirable. Modern scholars point out that the didascological approach gives and opportunity to influence teacher's professional consciousness, behavior, health (analogy of modern supervision in pedagogical activity) in the process of individual work with the teacher in active forms.

At this time, studies of Russian psychoanalyst scientists were interesting. The representatives of psychoanalytic pedagogy in the sphere of the human personality improvement, first of all, dreamed about nurturing a happy person who would spend their mental energy not to fight internal conflicts but could direct them to creativity and personal happiness [21, p. 179]. The first teacherspsychoanalysts set themselves a "global" task of general prevention of children and adolescents, sought to develop the socio-psychological competence of the teacher. Many educational theories and styles have been formally recognized as factors in the neurotic development of both children and educators due to the criticism of psychoanalyst educators. In the 1920s and 1930s, Russian psychoanalyst educators, in collaboration with psychologists from around the world, worked out the problems of education and harmonization of the human inner world. But the true goals of psychoanalysis were to help a person achieve personal happiness, harmony with others and himself - did not coincide with the goals of party leaders to educate a generation of obedient builders of communism, so the Russian unification was liquidate.

In Soviet times, the problem of the occupational deformation of the teacher was relatively "closed" for domestic scientists. Ideological paints were used to obscure the facts about the negative influence of the profession on the individual. It was considered that a specialist should not be emotionally exhausted at work, feel emotional discomfort when interacting with students, colleagues at work, while performing their functional duties, or talking about their professional incompetence, incapacity. Often, the problem of occupational deformation was associated with the non-professionalism, immorality of the personality of the teacher. Special studies on the negative impact of the profession on the health of the teacher in connection with the party-ideological line of leadership in science in the country have not been conducted for a long period, have been artificially removed from the range of current scientific problems.

In $1934 \mathrm{~V}$. Zenkovskyi drew attention to the complexity of pedagogical activity: "The teacher constantly thinks not about himself but about the child. The teacher always gives, but never receives" [22, p. 58]. The author noted that in order for a teacher to understand children, he must "fall to their level", and therefore "the teacher spontaneously does not go forward, but constantly falls to the level of his pupils in order to understand them and be clear" [22, p. 59]. Characterizing the specifics of pedagogical work and formulating his vision of the norm of the professional activity of the teacher, the scientist noted that it's not necessary to work with the children more than 15 years because after that, in addition to fatigue, the immobility (conservatism) is produced, the desire to keep to the pattern, self-confidence. V. Zenkovsky wrote that "Teacher psychology is very complex and difficult, and if something keeps the teacher inside, it is only pedagogical idealism. Pedagogical idealism has a great healing influence on the teacher, freeing him from all extremes and temptations" [22, p. 60].

The problem of preserving the health of the teacher was reflected in the works of A. Makarenko and V. Sukhomlinskyi. A. Makarenko wrote in his "Reflections" a bitter truth, which still sounds like a terrible social diagnosis to the teachers. "The teachers, he said, ... have a miserable look. At best, these are the people who learned their subject till the very end, who are driven from school to school in the early morning to late evening to earn as much as possible. In other cases, and mostly, they are tor- 
mented by poverty, impotence and family conditions, employees who are doing their jobs in the classroom, holding on to their place, more or less successfully avoiding dangerous quarrels and mockingbirds, who are not welldressed and have a place to live. The teacher receives a salary almost the same as the pay of the city cleaner or janitor, but the janitor receives clothes, and the teacher receives nothing but $100-120$ rubles. Naturally, this job is done by a person who is too weak to get any other job anymore" (Makarenko, as cited in [23, pp. 3-4]).

According to A. Makarenko, occupational deformations are manifested in the notations of teachers, in the severity, excessive "adult seriousness, artificially created by pedagogical gloom". That is why irritability, harshness and harsh screams, which the pupils do not forgive the teacher for, are unacceptable - wrote the great teacher. A. Makarenko emphasized the inadmissibility of deformation of the pedagogical team, the reason for which is a halt in its development. He states that the teacher must be able to manage his mood, be able to play to keep his nerves: "The teacher can not play. There can be no teacher who cannot play. We cannot allow our nerves to be a pedagogical tool, we cannot accept that we can nurture our children with the help of our heartache, the torment of our soul. We are people. And if in any other specialty you can do without mental suffering, then we should do it. But sometimes the student has to demonstrate the torment of the soul, and to do so he must be able to play" [24, p. 142].

The manifestation of occupational deformation V. Sukhomlynskyi saw in the spiritual "ossification" of the teacher, indifference to the student, disbelief that the student can do something good, in reconciliation with the idea that the bad student should stay a bad one [25, p. 39]. A means of prevention of deformation, exhaustion, fatigue is a continuous improvement of a teacher's professional potential. V. Sukhomlynskyi stated that "in three to five years after graduation, a teacher should know three, five, ten times more than he knew in the first year of his work. If this is not the case, the students will be doomed to boredom and dullness, because teaching, not warmed up and illuminated by the teacher's desire for knowledge, becomes a heavy-duty for him, a burden, and the child reflects any desire for knowledge and destroys its intellectual makings and ability" [25, p. 51].

V. Sukhomlynskyi warned teachers against negative emotions and their effects on health. He noted: "Misery, anger, indignation - not only worsen unpleasant experiences in his soul but also worsen the work of the internal organs. ... An educator's health disorder starts with the fact that it allows growing ill-health, which is a dangerous illness of the heart, which affects the heart and nerves". Then the teacher becomes a "bilious, irritable, gloomy creature", the work becomes hard labor for him and he "appears a hundred ulcers, a hundred vices" [26, pp. 425-432].

To preserve his health, V. Sukhomlinskyi advised to remember [27, p. 507]:

- love for children is the source from which new forces can be constantly drawn;
- optimism is an inexhaustible source of creative energy, the nerve forces of the teacher, the pupils, so the teacher must be able to "create in the music of childhood first of all light, life-giving tunes", the health of the teacher, the strength of his spirit depend on;

- the ability to forgive students, other people - a prerequisite for maintaining occupational health. "The teacher must have a paternal and maternal apology to the child's inability to control his will";

- to be positive about others, towards yourself;

- the mutual benevolence of the teacher and the children are the finest threads that unite the heart and through which a person understands a person without words, feels the subtlest touches, disturbances of another person's soul. In this mutual feeling of the heart, in the ability to read in the soul of man - an inexhaustible source of health;

- neurogenic disorders are often observed, among them the most unpleasant and often threatening is the exhaustion of nervous forces (the term "emotional burnout syndrome" in modern scientific literature) without the ability to "see and feel the world of childhood with its complex emotional harmony";

- activation of creativity is a prerequisite for preservation, strengthening of the emotional health of the teacher. Creating the riches of his emotional sphere, the teacher protects himself from emotional elements - this is the condition that masks him during times of failure and frustration (this is a state of frustration in pedagogical activity);

- it is necessary to bring the flexibility of the nervous system to the degree of "the art of power over emotions", to form emotional flexibility, to engage in self-education of feelings.

V. Sukhomlynskyi offers the teacher the means of relieving emotional tension, excitement and irritation, the means of promoting health. It is, first of all, the shifting of the energy of the whole team, including the teacher, into a work that requires spiritual unity, collective creativity, focus; secondly, it is humor without which a wall of mutual misunderstanding with the students arises; thirdly, the replenishment of nervous and spiritual forces, by the rational use of them in the process of daily work, as a very important guarantee of heart health and health of the spirit [26, pp. 425-429].

The analysis of psychological and pedagogical researches shows that the majority of scientific works of 1950-1970s years are devoted mainly to the formation of healthy lifestyles of children, adolescents, student youth. It is worth noting that at this time the most developed problem of forming a healthy lifestyle through physical culture and the science of health is emerging. First, it was called valeology and then - sanology. Subsequently, pedagogical valeology develops and pedagogical psycho-hygiene activities. 


\subsection{Development of the ideas for preserving and strengthening the professional health of teachers in the coordinates of psychology and pedagogy of health}

The beginning of the study of stress in the workplace was initiated by the American psychologists B. Margolis, W. Kroes, and R. Quinn, who in 1974 published the article "Occupational Stress: Unregistered Occupational Danger" [28]. In the 1980s, M. Litt and D. Turk even introduced the concept of "teacher stress" into scientific usage, which is interpreted as the experience of unpleasant emotions and physical pain that occurs when a teacher's wellbeing is threatened or when his ability to cope is exceeded urgent problems [29]. There are studies that present different models of occupational stress [30-32],occupational stress of teachers $[33,34]$.

The problem of mental burnout first appeared in the United States in the 1970s as a social problem rather than as a research construct. In the study's context of the negative impact of professional activity on the personality of the specialist, H. Freudenberger in 1974 introduced a special term "burnout". He interpreted this concept as a syndrome that contains symptoms of general physical fatigue and frustration in altruistic professions [35]. In 1978, the first article was published on the study of emotional burnout. Its authors, American scientists K. Maslach and S. Jackson [36], developed a multifactorial theory of burnout. They sought to find in the phenomenon of emotional burnout structure that would allow to make a deeper study and a quality diagnosis of its presence in specialists. Scientists interpret emotional burnout as a long-term response (reaction) of an employee to chronic interpersonal stressors at work. K. Maslach has the most famous description of emotional burnout: "Emotional burnout is a syndrome of emotional exhaustion, depersonalization and reduction of personal achievements, reduced personal accomplishment, which can occur among professionals engaged in various types of professions related to helping others" [37].

Some scholars do not limit the scope of emotional burnout to the professions of support and care. A. Pines and E. Aronson [38], for example, consider emotional burnout as a sign of fatigue that can occur in any profession, as well as outside of professional activities. According to A. Pines, burnout is a state of physical, emotional and mental exhaustion, which is caused by prolonged stay in emotionally stressful situations. According to him, burnout is the result of a failed search for meaning in life. The main cause of burnout is the need for people to believe in the importance and significance of their activities. Therefore, highly motivated individuals with inflated goals and expectations are most susceptible to burnout [39].

In the 1980s a constructive purposeful experimental study of burnout began. Various scientific ideas were supplemented by scientific research methods. As a result, many publications appeared and this problem began to be studied not only in the United States. Works [40-42] devoted to the problems of the emergence and prevention of professional burnout of teachers. To explain the phe- nomenon of mental burnout, scientists identify three main approaches: an individual approach that focuses on the symptoms experienced by individuals who have experienced burnout; interpersonal approach, which emphasizes the importance of interpersonal relationships in the occurrence of burnout; organizational approach, which considers the organizational environment important for understanding burnout. However, research does not pay enough attention to the study of the relationship between the personal characteristics of the teacher and professional burnout and there is a lack of empirical evidence.

It should be noted that in the 1980-1990s, special publications began to appear on the problems of the negative influence of the profession on the personality of the teacher, occupational deformations, occupational burnout, which, as noted above, were "relatively closed" for Soviet scientists in the previous period. This was facilitated by the emergence of a new scientific direction - the psychology of health. The father of health psychology is the American scientist D. Matarazzo [43], who in the 1970s proposed the term "health psychology" to describe a fresh field of application of psychology. The term has gained general recognition in the world of psychological science. Subsequently, this scientific direction emerges in Soviet and Ukrainian psychological science. The goal of health psychology is not only to prevent the development of mental and somatic pathologies but also to preserve, strengthen and holistically develop the spiritual, social and somatic components of health. New "positive" concepts of psychological health, as noted by G. Nikiforov, predict tendencies for development, growth, self-realization, self-realization of a person, conscious ability to manage their actions, be responsible to themselves and others, have a developed system of values, ability to adequately perceive themselves and others [5].

At the same time, there were works that explored resilience as a quality of personality. It is worth noting that the concept of resilience was empirically discovered or even opened more than 40 years ago. The introduction of the term "resilience" to psychological scientific terminology is attributed to the early works of E. Werner and R. Smith [44]. Since then, the term has been used by theorists and practitioners in various related disciplines and researched by scientists. This concept implies the ability to maintain resilience to external and internal threats without losing the pace of development [45]. A little later, there are works in which resilience is seen as a dynamic process that involves positive adaptation in the context of significant problems. S. Hobfoll, N. Stevens, and A. Zalta [46] interpret resilience as the ability to resist stressors and "return to one's pre-stress state when the stressor is over", demonstrating coping strategies. Strategically, coping strategies are part of achieving resilience. D. Fletcher, M. Sarkar [45] distinguish these concepts and believe that resilience affects how an event is evaluated, while coping refers to strategies that work after evaluating an encounter with a stressor. These studies have influenced the development of technologies of socio-psychological resilience to overcome the negative consequences of exposure to adverse circumstances and occupational difficulties, preven- 
tion of destructive behavior, ensuring the quality of further life and professional activities.

The end of the XX century is determined by a significant number of studies on resilience. It was during this period that researchers began to develop a variety of psychotechnologies for the prevention and development of resilience $[47,48]$. These technologies are not yet very actively implemented in the work to ensure the professional health of teachers.

Modern scientists approach the study of this phenomenon comprehensively. Thus, a follower of the constructivist approach to the study of resilience, D. Hellerstein, conceptualizing this phenomenon, identifies two main components - physical resilience as an indicator of stress and tolerance and psychological resilience, which includes the development and maintenance of social contacts, the use of social support in difficult events or situations, raising the level of education and mastering various psychotechnologies that help to develop and overcome the negative effects of stress [49].

At the end of the XX century, science revived research on the problem of orthobiosis of the individual, which means a person's mental health, a healthy lifestyle. A healthy, sensible way of life is a self-organization of an individual's life on the principles of ecology, optimism and positive activity [50, p. 93]. This led to the appearance of works in which measures were proposed to preserve the mental health of the teacher, to improve his psychological well-being.

In the modern psychological and pedagogical literature, a great deal of research is devoted to the study of the essential aspects, factors of occurrence of occupational stress, syndrome of "occupational burnout" of teachers $[4,51,52]$; the formation of healthy lifestyles, valeological literacy, valeological consciousness, valeological culture of future teachers $[2,3,53]$. Recently, there have been a number of works that address the issues of prevention of the syndrome of "occupational burnout" of teachers, occupational stress [54, 55], preparation of future teachers for health-creative activity $[52,56]$.

Today an interdisciplinary branch of knowledge and practical activity is developing, which solves the problem of preserving and strengthening the psychological health of students and the occupational health of teachers - pedagogical health psychology. Much more attention is needed to research the diagnosis of occupational health, the development of preventive measures and ways to preserve and strengthen the occupational health of the teacher, formulate an optimal health strategy, increase the level of stress of the teacher, justify methods of harmonizing his inner world.

The Concept of Development of Teacher Education [57] emphasizes the personal and professional growth of the teacher, his academic freedom, motivation, the need to develop the teacher's health-saving competence. The health of the teacher is determined by the necessary prerequisite for the competent performance of his / her functional duties and at the same time an important component of his / her professional suitability.
The practice of conducting anti-burnout trainings, antistress trainings, self-efficacy trainings, personal and professional growth trainings is becoming widespread. This is especially observed in the system of postgraduate pedagogical education. Similar activities are carried out at the national level by the Academy of Innovative Development of Education with the support of the Ministry of Education of Ukraine in the framework of the scientific and pedagogical project "Training of management, pedagogical and scientific-pedagogical staff to work on innovative technologies". In this context, research is of interest in the development of stress resistance of specialists [54]; anti-burnout training [52]; training programs to increase the level of professional stress resistance of special teachers $[55,58,59]$. The main focus is on the development of psychological and pedagogical means of activating the personal resources of the teacher [60], which will contribute to the preservation and enhancement of his/her occupational health.

\section{Discussion and conclusions}

Maintaining and strengthening the teachers' professional health has always been and remains to be an urgent problem of pedagogical and psychological science. Therefore, it is important to trace the state of development and genesis of this problem's research in the history of scientific thought and the practice and to identify positive ideas for their creative use in modern conditions.

The study attempted to analyze the problem of teachers' professional health maintaining and strengthening in the retrospective. The analysis shows the issues that outline this problem have were not studied separately but in the context of maintaining and strengthening human health in general. Thinkers and researchers of different times have focused their research mainly on the formation of a culture of health, a healthy lifestyle, including and teacher. In the professional sphere, these problems have been studied in the context of the scientific organization of labor, optimization of management and safety of production, increasing vital energy, the impact on the performance of occupational fatigue, etc. A retrospective analysis revealed that research on the analysis of the professional health of teachers is relevant in the early twentieth century and is associated primarily with the study of emotional overload of teachers, occupational fatigue, related problems of occupational deformities of the teacher, and so on. These issues were considered mainly in the field of valeology, sanology, pedagogical psychohygiene, and since the end of the XX century - and health psychology, pedagogical psychology of health.

The study traces the genesis and characterizes the periods of studying the problem of preserving and strengthening the teachers' professional health, areas of research in the history of scientific thought (early XX century - early XXI century).

Based on the results of the study, such periods are singled out in the study of the problem of preserving and promoting the occupational health of the teacher: 
1) $1900-1920 \mathrm{~s}$ characterized by the emergence of the movement for the scientific organization of work, the development of issues of ensuring the health of workers. US scientists investigated the problems of work organization optimization, production safety, improving working capacity, overcoming occupational fatigue. This period is characterized by considerable experience of pedagogical education in Russia, in particular, the Commission for the Study of Teacher Labor on the study of the conditions and mechanisms of the emergence of occupational maladaptation, occupational deformations, finding out occupational difficulties, their impact on the health of the teacher. The results of these studies are relevant today. The pedagogical direction didascology as a complex science about the teacher is presented. It is proposed to create an independent didascological institute. Complex researches of teachers are carried out. Such research is very necessary today. In the context of this problem, the research of psychoanalyst educators of the time, due to which many educational theories and styles had been formally recognized as factors of neurotic development of both children and educators, deserves attention.

2) 1930-1950s. In Soviet times, the problem of the occupational deformation of the teacher was relatively "closed" for domestic scientists. Ideological paints obscured the facts of the negative impact of the profession on the individual. Special studies in the field of the negative influence of the profession on health of the teacher in connection with the party-ideological line of leadership of science in the country were not conducted and artificially removed from the spectrum of important scientific problems. The views of A. Makarenko and V. Sukhomlinsky about the reasons for the teacher's health deterioration, the ways and means of relieving emotional stress, and improving his psychological well-being are extremely relevant today.

3) 1960-1980s. Most scientific works of this period are devoted mainly to the formation of healthy lifestyles of children, adolescents, student youth. It is worth noting that at this time the most developed problem of forming a healthy lifestyle through physical culture and the science of health were emerging. First, it was called valeology and then - sanology Subsequently, pedagogical valeology and pedagogical psycho-hygiene activities developed. 1970-1980s formed a new scientific direction - the psychology of health. The goal of this area is not only to prevent the development of mental and somatic pathologies but also to preserve, strengthen the holistic development of the mental, social and somatic components of health.

4) $1990 \mathrm{~s}$ and the beginning of the XXI century. Scientific works of scientists of this period are devoted to the problems of formation of valeological consciousness, valeological culture, healthy way of life, culture of health of teachers, preparation of future teachers for health-creative activity. Studies on health psychology are being conducted. There is an active interdis- ciplinary branch of knowledge and practical activity that explores the problems of preserving and strengthening the psychological health of students and the occupational health of teachers - pedagogical health psychology. In the system of postgraduate pedagogical education, the practice of conducting anti-burn training, anti-stress training, self-efficacy training, personal and professional growth training aimed at activating the teacher's resources, developing his autopsychological competence, an increase of the level of resilience, harmonization of the person that will promote preservation and strengthening of occupational health.

Practically oriented directions of the professional health preservation and strengthening problem research, which is connected with the development of preventive measures and ways of preservation and strengthening of teachers' professional health (including in the conditions of quarantine caused by coronavirus infection [61-63]); increasing the level of stress resistance of teachers and the development of their resilience; prevention of professional deformations; formation of readiness for self-rehabilitation. The issues of purposeful preparation of future teachers for maintaining and strengthening professional health at the stage of higher education are important.

We see the prospects of our further scientific research in the problem's study of stress resistance and resilience of teachers at the stage of training in higher education and the system of formal and informal pedagogical education, and in developing ways to implement research results in practice, in particular, in the centres of pedagogical consulting.

\section{References}

[1] A. Bereza, ed., Development and modernization of pedagogical and psychological sciences: experience of Poland and prospects of Ukraine (Baltija Publishing, Lublin, 2017), pp. 206-223

[2] S. Kyrylenko, Pedahohika i psykholohiia: Visnyk APN Ukrainy 342, 48 (2004)

[3] V. Bobrytska, Native school pp. 15-18 (2005)

[4] N. Nazaruk, in Zbirnyk naukovykh prats: filosofiia, sotsiolohiia, psykholohiia (Play, Ivano-Frankivsk, 2004), Vol. 9, pp. 186-194

[5] G. Nikiforov, ed., Psihologija zdorov'ja (Psychology of health) (Piter, Saint Petersburg, 2006)

[6] F.W. Taylor, Scientific management (Routledge, 2004)

[7] M.J. Nadworny, Business History Review 31, 23-34 (1957)

[8] A. Baumgart, D. Neuhauser, BMJ Quality \& Safety 18, 413 (2009)

[9] K. Stamatopoulou, Lillian Moller Gilbreth (2017), https://shethoughtit.ilcml.com/ biography/lillian-moller-gilbreth/

[10] V. Bekhterev, Suggestion and its role in social life (Routledge, 2017)

[11] K.E. Bailes, Soviet Studies 29, 373 (1977) 
[12] T. Markaryan, School, child and teacher education and didascology, 2nd edn. (1925)

[13] A. Gordeeva, Reabilitacionnaja pedagogika: professional'naja reabilitacija pedagoga (Rehabilitation pedagogy: professional rehabilitation of the teacher) (APK i PRO, Moscow, 2000)

[14] I.M. Burdianskii, ed., Izuchenie professii intelligentnogo truda (Voprosy truda, 1925)

[15] I. Ravkin, Y. Sokolov, eds., Trud i zdorove pedagoga (Rabotnik prosveshcheniia, 1926)

[16] T. Formanjuk, Voprosy psihologii 3, 57 (1994)

[17] L. Vygotsky, Pedagogicheskaja psihologija (Educational psychology) (Pedagogika, Moscow, 1991)

[18] M.M. Rubinshtein, Problema uchitelia (Mosk. aktcioner. izd. o-vo, 1927), http://elib.gnpbu . $\mathrm{ru} /$ textpage $/$ download $/ \mathrm{html} /$ ?bookhl=\&book= rubinshteyn_problema-uchitelya_1927

[19] V.P. Kashkadamov, Gigiena umstvennogo truda, 2nd edn. (Rabotnik prosveshcheniia, 1929)

[20] L. Burlachuk, E. Ju.Korzhova, Psihologija zhiznennyh situacij (Psychology of life situations) (Ped. agenstvo, Moscow, 1998)

[21] L. Obrazcova, Passionarii psihoanaliticheskoj pedagogiki (Passionaries of psychoanalytic pedagogy) (PGPI, Piatigorsk, 2006)

[22] V. Zenkovskyi, Pedahohika (Pedagogy) (Vseukrainske pravoslavne pedahohichne tovarystvo, Kyiv, 2006)

[23] V. Ghromovyi, Dyrektor shkoly 385, 3 (1994)

[24] A. Makarenko, in Izbrannye proizvedenija v 3 tomah, edited by N.D. Yarmachenko (Radianska shkola, Kyiv, 1985), Vol. 3

[25] V. Sukhomlynskyi, in Vybrani tvory v 5 tomakh, edited by O.G. Dzeverin (Radianska shkola, Kyiv, 1976), Vol. 4, pp. 7-390

[26] V. Sukhomlynskyi, in Vybrani tvory v 5 tomakh, edited by O.G. Dzeverin (Radianska shkola, Kyiv, 1976), Vol. 2, pp. 419-654

[27] V. Sukhomlynskyi, in Vybrani tvory v 5 tomakh, edited by O.G. Dzeverin (Radianska shkola, Kyiv, 1976), Vol. 3, pp. 283-582

[28] B. Margolis, W.A. Kroes, R.P. Quinn, J. Occup. Med. Toxicol. 16, 659 (1974)

[29] M.D. Litt, D.C. Turk, The Journal of Educational Research 78, 178 (1985)

[30] R. Karasek, T. Theorell, Healthy work: stress, productivity, and the reconstruction of working life (Basic Books, New York, 1990)

[31] M. Smith, P. Carayon, in Beyond Biomechanics: psychosocial aspects of musculoskeletal disorders in office work, edited by S.L. Sauter, S.D. Moon (Taylor and Francis Group, London, 1996), pp. 23-42

[32] R. Lazarus, The International Journal of Psychiatry in Medicine 5, 321 (1974)

[33] B.A. Farber, The Journal of Educational Research 77, 325 (1984)

[34] C. Kyriacou, J. Sutcliffe, Educational Review 29, 299 (1977)
[35] H. Freudenberge, Joumal of Social Issues 30, 159 (1974)

[36] C. Maslach, S.E. Jackson, Journal of Occupational Behavior 2, 99 (1981)

[37] C. Maslach, Public Welfare 36, 56 (1978)

[38] A. Pines, E. Aronson, Career burnout: Causes and cures (Free Press, New York, 1988)

[39] A. Pines, Teachers and Teaching: Theory and Practice 8, 121 (2002)

[40] M. Fimian, Journal of Occupational Psychology 57, 277 (1984)

[41] M. Fimian, L.P. Blanton, Journal of Occupational Behaviour 8, 157 (1987)

[42] J. Sharit, G. Salvendy, Human Factors 24, 129 (1982)

[43] J. Matarazzo, in Master lecture series, edited by B.L. Hammonds, C.J. Scheirer (Psychology and health, American Psychological Association, 1984), Vol. 3, pp. $9-43$

[44] E. Werner, R. Smith, Overcoming the odds: high risk children from birth to adulthood (Cornell University Press, Ithaca, New York, 1992)

[45] D. Fletcher, M. Sarkar, European Psychologist 18, 12 (2013)

[46] S.E. Hobfoll, N.R. Stevens, A.K. Zalta, Psychological Inquiry 26, 174 (2015)

[47] K. Bolton, The development and validation of the resilience protective factors inventory: a confirmatory factor analysis (The University of Texas at Arlington, Arlington, TX, 2013)

[48] A. Masten, Ordinary magic: resilience in development (The Gulford press, New York, 2014)

[49] D. Hellerstein, How can I become more resilient?, https://www.psychologytoday. com/intl/blog/heal-your-brain/201108/ how-can-i-become-more-resilient

[50] L. Makarova, Y.M. Hakh, Osnovy psykholohii $i$ pedahohiky (Fundamentals of psychology and pedagogy) (Tsentr navchalnoi literatury, Kyiv, 2005)

[51] V. Rozov, Adaptyvni antystresovi tekhnolohii (Adaptive anti-stress technologies) (Kondor, Kyiv, 2005)

[52] T.V. Zaichikova, 3(24), 135 (2008)

[53] Y.D. Boychuk, Ekoloho-valeolohichna kultura maibutnoho vchytelia: teoretyko-metodychni aspekty (Ecological and valeological culture of the future teacher: the theoretical and methodical aspects) (Universytetska knyha, Sumy, 2008)

[54] H.M. Dubchak, Psykholohichni osnovy profesiinoi stresostiikosti maibutnikh fakhivtsiv (Psychological bases of professional stress resistance of future specialists) (Talkom, Kyiv, 2017)

[55] N.Y. Tsybuliak, Naukovyi visnyk Khersonskoho derzhavnoho universytetu 4, 266 (2019)

[56] H. Meshko, Teoriia i praktyka pidhotovky maibutnikh uchyteliv do zberezhennia i zmitsnennia profesiinoho zdorovia (Theory and practice of preparing future teachers to preserve and promote occupational health) (TNPU im. V. Hnatiuka, Ternopil, 2018) 
[57] Ministry of Education and Science of Ukraine, Koncepcija rozvytku pedaghoghichnoji osvity (The concept of development of pedagogical education), https://mon.gov.ua/storage/ app/uploads/public/5b7/b\-b2/dcc/ 5b7bb2dcc424a809787929.pdf

[58] E. Kiel, U. Heimlich, R. Markowetz, A. Braun, S. Weib, European Journal of Special Needs Education 31, 202 (2016)

[59] C. Kokkinos, A.M. Davazoglou, Educational Psychology 4, 407 (2009)
[60] H. Meshko, O. Meshko, N. Drobyk, O. Mikheienko, E3S Web of Conferences 166 (2020)

[61] L. Bakhmat, O. Babakina, Y. Belmaz, Journal of Physics: Conference Series 1840, 012050 (2021)

[62] I. Trubavina, S. Dotsenko, O. Naboka, M. Chaikovskyi, H. Meshko, Journal of Physics: Conference Series 1840, 012052 (2021)

[63] M. Velykodna, Psychodynamic Practice 27, 10 (2021) 